\title{
Selected Reference Books of 1979-80
}

$\mathbf{T}$ 1 HIS ARTICLE continues the semiannual series originally edited by Constance $\mathbf{M}$. Winchell. Although it appears under a byline, the list is a project of the Reference Department of the Columbia University Libraries, and notes are signed with the initials of the individual staff members. ${ }^{1}$

Since the purpose of the list is to present a selection of recent scholarly and general works of interest to reference workers in university libraries, it does not pretend to be either well balanced or comprehensive. A brief roundup of new editions of standard works, continuations, and supplements is presented at the end of the article. Code numbers (such as BD371, CA23) have been used to refer to titles in the Guide to Reference Books and its supplement. ${ }^{2}$

\section{BIBLIOGRAPHY}

U.S. Library of Congress. Catalog Publication Division. The Slavic Cyrillic Union Catalog of Pre-1956 Imprints. Totowa, N.J., Rowman and Littlefield, 1980. Microfiche (positive); 174 sheets. $11 \times$ $15 \mathrm{~cm}$. \$495. LC 80-80218.

Scholars and students of Slavic studies, to say nothing of interlibrary loan librarians, will welcome this work as the successor to the Cyrillic Union Catalog (Guide AA856). The scope of the new work is considerably expanded over the earlier version, listing books, pamphlets, maps, atlases, periodicals, and other serials published before 1956 in the Cyrillic alphabet and in seven languages: Russian, Church Slavic, Belorussian, Ukrainian, Bulgarian, Serbian, and

1. Paul Cohen, Rita Keckeissen, Anita Lowry, Eileen McIlvaine, Mary Ann Miller; Lehman Library: Laura Binkowski, Diane Goon.

2. Eugene P. Sheehy, Guide to Reference Books (9th ed.; Chicago: American Library Assn., 1976); Supplement (Chicago: American Library Assn., 1980).
Macedonian. It represents well over 350,000 titles (main and added entries and cross-references) cataloged by the Library of Congress and participating libraries and held by 220 libraries in the United States and Canada. When CUC was published in 1963 , it included locational information up to March 1956. Over the last two decades locations continued to be recorded in the Slavic Union Catalog at the Library of Congress, and this information is now incorporated into SCUC. Starting in 1980, further locations for these materials will appear in the National Register of Additional Locations under the SCUC card number.

Arrangement is a single alphabet by main entry. Essential added entries and crossreferences are included, but the main entry must be consulted for locations. Whereas the $C U C$ used a romanized form throughout, SCUC was prepared from Library of Congress cards wherever possible and contains only a small percentage of entries using transliteration. No attempt was made to edit for conformity with LC practice the variations in contributed copy for which no LC card existed. Consequently, the searcher must be aware that inconsistencies are to be expected.

Fiches are of a forty-eight-diameter reduction with twelve cards to a frame. Frames are arranged in the comic mode, but the individual frame consists of three columns of four cards each, to be read by column. Some few handwritten cards and those on colored stock are difficult or impossible to read, but despite all its imperfections, SCUC will be recognized as an enormously valuable research tool.-R.K.

\section{MANUSCRIPTS}

Henry E. Huntington Library and Art Gallery, San Marino, California. Guide to American Historical Manuscripts in the Huntington Library. [San Marino], Hunt- 
ington Library, 1979. 442p. \$25. LC 7852568. ISBN 0-87328-100-4.

Guide to Literary Manuscripts in

the Huntington Library. [San Marino], Huntington Library, 1979. 539p. \$35. LC 79-84369. ISBN 0-87328-102-0.

With more than five million manuscripts in its collections, the Huntington Library is one of the richest depositories in the country. In 1975 the library began a survey of these holdings which has so far resulted in two published guides giving detailed information about the collections: literary manuscripts and American historical manuscripts.

The historical volume covers materials dating from the sixteenth century; each entry in the guide includes a well-researched historical or biographical sketch, an account of the subject matter, a list of significant correspondents represented, a physical description of the papers, and the provenance, as well as any useful bibliographical sources. More than 500 separate collections are described in this manner, making the volume a useful reference work even for those not searching for the manuscripts themselves.

Holdings described in the volume devoted to literary manuscripts include some 125,000 pieces written by more than 1,000 authors. It was not possible to give descriptions here as full as those in the historical volume. Biographical notes, for example, are included only for the largest collections. However the manuscripts themselves are listed in some detail, often with a brief description and usually dated.

In 1981 the final two volumes of this guide series are scheduled for publication: British historical manuscripts, and medieval and Renaissance manuscripts. Together, these four volumes will greatly facilitate using the Huntington Library; they will also serve as a model for compilers of manuscript catalogs for other libraries.-P.C.

Matthews, Noel, and Wainright, Mary Doreen, comps. A Guide to Manuscripts and Documents in the British Isles Relating to the Middle East and North Africa. Ed. by J. D. Pearson. [Oxford], Oxford Univ. Pr., 1980. 482p. £50. LC 79-40621. ISBN 0-19-713598-6.

In 1965 Matthews and Wainwright made a survey of British libraries (including those of museums and learned societies) to identify holdings of Western-language manuscripts relating to Asia and Africa. This is the last of the guides based on that survey, earlier volumes having covered South and Southeast Asia (1965; Guide DE15), Africa (1971; Guide DD59), and the Far East (1977; Suppl. DE2). J. D. Pearson has updated the original survey information: he has perused descriptions or inventories published since 1965; revisited the main libraries in London, Oxford, and Cambridge; and used the notes from the National Register of Archives and, for private papers, the Middle East Centre in Oxford. Thus he has provided an important catalog of manuscript materials in the British Isles dealing with the Arab countries, Israel, Cyprus, Turkey, Iran, and regions of the Caucasus, Central Asia, and the Crimea.

For each archive a note indicates any published guides or inventories of the collection, and this is followed by brief description of the contents of pertinent files. The index is very detailed.

Scholars are fortunate to have this useful series of guides, and they will be grateful to have had such a knowledgeable editor as Pearson for this one.-E.M.

\section{PERIODICALS}

Hoornstra, Jean, and Heath, Trudy. American Periodicals, 1741-1900; an Index to the Microfilm Collections: American Periodicals, 18th Century; American Periodicals, 1800-1850; American Periodicals, 1850-1900, Civil War and Reconstruction. Ann Arbor, Mich., University Microfilms International, 1979. 341p. \$62. LC 79-63165. ISBN 0-83570374-6.

Libraries that purchased University Microfilms' American Periodicals series now have an impressive index to those collections. It has title, editor, subject, and reel indexes to a significant group of periodicals published in America from the first one issued, The American Magazine (1741), through the nineteenth century. The index is the culmination of a project started forty years ago at the University of Michigan's Clements Library, where filming of rare 
eighteenth-century periodicals was begun on a small scale. Over the years periodicals from other libraries were added, not only making the series more complete but also making available the best copies for general use. When the three microfilm sets mentioned in the subtitle were complete, serials from more than 250 libraries were represented and the number of periodicals totaled more than 1,100 . More than simply a guide to these collections, the index serves as an important reference work on eighteenth- and nineteenth-century publishing history.

Each entry is accompanied by a historical note similar to those in Brigham's History and Bibliography of American Newspapers. Here editorial policies are chronicled, activities and contributors are described, and general history is traced. Lists of editors are also provided, along with pertinent bibliographical data (e.g., information on supplements and pagination) and a description of the actual paper copy microfilmed (indicating such matters as missing issues and damaged leaves). Even libraries that do not own the microfilm collections will find this index a valuable guide to the rich history of American periodical publishing.-P.C.

\section{NEWSPAPERS}

Merrill, John Calhoun, and Fisher, Harold A. The World's Great Dailies: Profiles of Fifty Newspapers. New York, Hastings, [1980]. 399p. il. $\$ 18.50 ; \$ 9.50$ paper. LC 79-19075. ISBN 0-8038-8095-2.

Abandoning the system of ranking used in Merrill's Elite Press (New York, 1968), the editors here present profiles of the newspapers that they believe "represent the very best in the world's journalism, regardless of how differently this journalism may manifest itself in different cultures and ideological contexts."-Pref. Nearly half of the papers profiled are English-language publications (ten from the USA), but the selection is worldwide and many different countries and languages are represented. An average of about seven pages (including an illustration of a typical front page) is devoted to each newspaper, with information provided on the history, policies, staff, circulation, strengths, and limitations. Sketches are highly readable and include bibliographic footnotes, but a fuller bibliography than the selected list found on pages $375-79$ would have been welcome.-E.S.

\section{BIOGRAPHY}

Biografisch Woordenboek van Nederland. Onder eindredactie van Dr. J. Charité. 's-Gravenhage, Nijhoff, 1979- . v.1- . (In progress) (v.l: 680p. 125f.) LC 80481300. ISBN 9-0247-2278-0.

Following the completion in 1937 of the Nieuw Nederlandsch Biografisch Woordenboek (Guide AJ240), there was no ongoing effort toward a dictionary of national biography for the Netherlands until work was begun on this new compilation. Inasmuch as the $N N B W$ included only persons deceased before the end of 1910, there is a considerable gap to be filled by the new series. As in the $N N B W$, each volume of the new set will offer an alphabetical sequence of articles with, presumably, cumulative indexes in subsequent volumes. Only deceased persons are included (with dates as late as 1977 noted in volume 1), but coverage is meant to be broad in regard to fields of endeavor, and nationals of other countries are included if their work or influence was notable in the Netherlands. Articles are signed and provide references to principal published writings of the biographees, collections of documents and archival materials, and biographical/critical studies.-E.S.

\section{LINGUISTICS}

Linguistic Atlas of the Middle and South Atlantic States. Ed. in chief, Raven I. McDavid, Jr. Chicago, Univ. of Chicago Pr., [1980- ] Fasc. 1-2. (In progress) $\$ 15$ per fasc. LC $79-24748$. ISBN $0-226-$ 55742-1; 0-226-55744-8.

At head of title: Linguistic Atlas of the United States and Canada, Hans Kurath, Director.

"Sponsored by the American Council of Learned Societies."-t.p.

In the 1930s and 1940s Hans Kurath directed a team of field workers who visited the Middle and South Atlantic states-from southern Ontario and upstate New York to northeastern Florida - to interview residents of specified communities for examples of 
pronunciation and grammatical usage. In each community (usually a county) an average of two "informants of contrasting age and social background . . . and often at different locations within the county" (Introd.) were chosen. For a few metropolitan areas such as Manhattan, Brooklyn, and Atlanta, six to eight people were interviewed.

After long delay, the first two fascicles of the atlas have been issued; these give the results of the survey for the pronunciation of "New England," state names, and "Philadelphia," "Baltimore," and "Washington," as well as county name of the informant. Transcriptions of pronunciations are given in a modified International Phonetic Alphabet. A "Table of Informants by Types" gives the age and sex of each informant, date of the interview, and the initials of the field worker.

Before relinquishing editorship of the project, Kurath decided that the format would not be overprinted maps as in the Linguistic Atlas of New England (Guide BC59), but rather "lists, printed by photooffset from typed copy. This would permit less costly publication and produce volumes easier to use and store."-Pref. There is no projected timetable for the completion of the atlas, but an index is expected to be ready at the time the last fascicle is published. Also in progress is a "LAMSAS handbook," which will provide a more detailed introduction to the project and its informants. Together with the Linguistic Atlas of New England, the completed LAMSAS will offer "the full phonetic record of the primary dialect survey of the Atlantic States . . . where the chief varieties of our English developed during the colonial period, dialects that were carried westward in the nineteenth century."-E.M.

\section{LITERATURE}

Fisher, Lois H. A Literary Gazetteer of England. New York, McGraw-Hill, [1980]. 740p. il. \$39.50. LC 79-22776. ISBN 0-07-021098-5.

Like Eagle and Carnell's Oxford Literary Guide to the British Isles (Oxford, 1977. 413 p.), this work offers an alphabetically arranged series of articles on places-towns, villages, rivers, mountains, etc.-with literary associations. But, apart from being more elaborately produced and confined to places in England, this volume exhibits various other differences from the Oxford work. Each volume includes certain place-names not found in the other, and different literary associations are sometimes singled out for the same place. Fisher's articles are almost always longer, more discursive in style, and more often include quotations from literary works. However, despite its length (p.322477 ), the "London" entry in Fisher, consisting mainly of entries for individual writers (arranged by birth date) and detailing their association with the city, seems generally less satisfactory than that in the Oxford work, which is subdivided by area, with entries for named districts, streets, and even specific buildings. The Oxford volume's unusually full "Index of Authors" also offers advantages over Fisher's index. Large libraries, however, will undoubtedly want both works.-E.S.

Grant, Michael. Greek and Latin Authors, 800 B.C.-A.D. 1000; a Biographical Dictionary. New York, Wilson, 1980. 490p. il. \$25. LC 79-27446. ISBN 0-8242-06401.

This latest addition to the Wilson Authors series is a handy compilation of biographical-critical articles on 376 authors of ancient and early medieval times, the period that precedes the publisher's European Authors: 1000-1900 (Guide BD88). Entries, alphabetically arranged, cover the writer's life, identify and describe the contents of his works, and, for the more important authors, indicate his influence on later literature. The bibliography that concludes each account lists the most useful editions of the writings, translations, and critical materials, thus providing the student with a good starting point for further investigation. Two appendixes offer a list of works of doubtful attribution and a chronological list of authors by century. Valuable for any reference collection, especially in the smaller library. $-R . K$.

Howard-Hill, Trevor Howard. British Bibliography and Textual Criticism: A Bibliography. Oxford, Clarendon Pr., 
1979. 2v. (Index to British Literary Bibliography, v.4-5) $£ 45$ the set. LC 7730735. ISBN 0-19-818163-9.

As the author states in the introduction to the first volume of this set, "This bibliography records writings in English published from 1890 which discuss bibliographical aspects of works printed or published in Britain from 1475 to the present day, and the circumstances of production and distribution of books in Britain during that period. From the literary viewpoint, the bibliography provides access to the literature of which a student or editor must take account when he attempts to determine the authority and correctness of a text which interests him." The principles of inclusion and exclusion for the bibliography are enumerated in careful detail, but without noting the numerous exceptions (for example, certain foreign-language materials) to the general rules, one can summarize the scope of the bibliography as follows: Englishlanguage books and articles published between 1890 and 1969 that are concerned primarily with the bibliographical and textual questions of English literary history.

For the most part, the style and arrangement of entries are consistent with the earlier volumes in the Index to British Literary Bibliography series: Bibliography of British Literary Bibliographies (1969; Guide BD371) and Shakespearean Bibliography and Textual Criticism (1971; Guide BD528). The entries are grouped in six sections: "Bibliography and Textual Criticism"; "General and Period Bibliography"; "Regional Bibliography"; "Book Production and Distribution"; "Forms, Genres, and Subjects" (all in one volume); and "Authors" (in the second physical volume). Within each section entries are arranged chronologically. A combined index to the four published volumes of the series (v. 3, British Bibliography to 1890 , is still in preparation), announced for June 1980 publication, was not available for examination, but the completed work will constitute a major scholarly reference work. $-A . L$.

World Authors, 1970-1975. Ed., John Wakeman. New York, Wilson, 1980. 894 p. ports. $\$ 40$. LC 79-21874. ISBN 08242-0641-X.

Designated as a volume in the Wilson
Authors series, this volume is called "a companion rather than a supplement" to such earlier Wilson biographical dictionaries as Twentieth Century Authors (Guide BD89) and World Authors, 1950-1970 (Suppl. BD20) because it does not update biographies of authors dealt with in those works. Some 348 writers are represented, most of them being novelists, poets, or dramatists "of literary importance and/or exceptional popularity" (Pref.), although philosophers, historians, biographers, critics, scientists, and journalists are included if their writings seemed of "sufficiently wide interest, influence, or literary merit." Most came to prominence during the 1970-75 period, but a number of figures omitted from earlier volumes (because of lack of biographical information or because their work was not available in English translation) are included here. Articles employ the combination of biographical material (with autobiographical statements provided by many of the biographees) and critical comment familiar to users of the Wilson series. Lists of principal writings and of writings about the authors complete the entries.E.S.

\section{Cinema Studies}

Cinema; a Critical Dictionary: The Major Film-makers. Ed. by Richard Roud. New York, Viking, 1980. 2v. il. \$75. LC 7921892. ISBN 0-670-22257-7.

To appreciate the merits and value of this book as a reference source, one must first understand what it is not. It is not an objective, comprehensive dictionary of film and film making; it is not a biographical dictionary (though entries for individuals predominate); it is not, primarily, a source of dates or facts or film titles. It is a collection of analytical, critical articles on a selected list of film directors, as well as on a few important actors, genres, national cinemas, and on two films, The Cabinet of $\mathrm{Dr}$. Caligari and Gone with the Wind (included as illustrations of the collaborative nature of film making). In a twenty-page introduction, the editor (director of the New York Film Festival) explains his critical assumptions and preferences as well as his general evaluation of film theory and history; this introduction is important because the nature 
of the dictionary is determined by Roud's thinking about cinema-from the selection of subjects, contributors, and format to the personal comments added by Roud at the end of each article (comments that update, supplement, evaluate, and add bibliographical references).

Emphasis is primarily, though not exclusively, on feature-length, narrative cinema of the United States, Western Europe, Russia, and Japan. All of the generally accepted major directors are included, plus many lesser-known ones. Among other topics afforded separate articles are "American Avant-Garde Cinema," "Dance in Film," "Soviet Cinema since the War." The contributors are well-known scholars and critics; the articles reflect a variety of styles and approaches, and range from a few paragraphs to many pages.

As a reference work, this is a valuable source of concise, analytical essays of a kind that cannot be found in any other English-language reference book in the field; indeed, for some of its subjects it may provide the only (or at least the most accessible) critical survey in English. The index of names and titles and the well-reproduced stills enhance the book's usefulness.-A.L.

\section{PHOTOGRAPHY}

Moss, Martha. Photography Books Index: A Subject Guide to Photo Anthologies. Metuchen, N.J., Scarecrow, 1980. 286p. \$15. LC 79-26938. ISBN 0-810-81283-5.

This guide seeks to provide access to some of the important but elusive documents of photographic history. By indexing twenty-two books of collected photographs, it enables the student or researcher to identify and locate published reproductions of "thousands" of photographs. The volumes indexed are, for the most part, general photo anthologies and major histories of photography, including six volumes in the Time-Life photography series. Citations to photographs are listed in three sections: by photographer, by subject (using subject headings drawn mainly from the Sears List of Subject Headings), and portraits by name of sitter. For each photograph the following information is given: photographer, title, date, list of sources (with page or plate number), whether it is a color reproduction, and descriptive title for untitled photographs. Full citations to the sources are found in the "List of Books Indexed." Supplementary volumes are planned.-A.L.

\section{GRANTS}

White, Virginia P. Grants for the Arts. New York, Plenum, [1980]. 360p. \$19.50 LC 79-18043. ISBN 0-306-40270-0

Coleman, William E. Grants in the Humanities: A Scholar's Guide to Funding Sources. New York, Neal-Schuman, [1980]. 152p. \$12.95 paper. LC 79-25697. ISBN 0-918212-21-9.

Nowadays there is a burgeoning of new guides, directories, and journals to aid groups and individuals in their quest for the keys to the kingdom of patronage, and Virginia White leads the crowd with her ability to inspire while creating the order and perspective necessary for successful grantsmanship. She has previously given us one of the best general guides to grant seeking (Grants, 1975; Suppl. CA23) and here turns her experienced hand to helping a group that has heretofore not had a good guide of its own. To warm the grant seeker to the task she offers a fascinating historical essay on the history of artists and patrons. Noting the subtleties of grantsmanship from one discipline to another, she holds that philanthropists in the arts do not act out of compassion, altruism, or social concern; rather, "arts groups and artists are the means by which many sponsors try to make their own dreams come true. Understanding this important fact is essential in establishing a favorable relationship with a grantor."$p .17$. Even so, having sometimes been disappointed, sponsors of the arts are now as hard-nosed as grantors in other fields, so the remaining fourteen chapters and six appendixes of White's guide are devoted to such tasks as identifying potential funding sources, managing the informal negotiations preceding the submission of an application, and preparing the written application. She covers government, corporate, and foundation sources, lists helpers such as "volunteer lawyers for the arts organizations," and provides sample budgets.

Coleman's book echoes much of White's advice and information, but it is most signif- 
icantly a list of agencies interested in funding individuals for postdoctoral research without geographic limitations. He has found and indexed by subject more than 130 such agencies and hopes for an annual revision of the list. The definition of humanities used by Coleman includes "the history, theory and practice of the arts" along with other disciplines and studies considered humanistic, and thus serves for some as an excellent companion to White's guides. For many other humanists it will be their best primary guide and directory.-M.A.M.

\section{SOCIOLOGY}

History of the Family and Kinship: A Select International Bibliography. Ed. by Gerald L. Soliday. Millwood, N.Y., Kraus International Publs., 1980. 410p. \$45. LC 80-11782. ISBN 0-527-84451-9.

This bibliography is the published result of a special project of the Journal of Family History that was funded by a grant from the National Endowment for the Humanities. Coverage is worldwide and systematic through 1976. The 6,200 entries are grouped by regional or national units and are usually subdivided chronologically, with two exceptions: an excellent introductory chapter, and a chapter on classical antiquity. The organization of each chapter enhances its usefulness, beginning with works of a general nature, bibliographies, review essays, and methodological sources, followed by topic-specific citations. References contain a minimum of bibliographic information. A name index concludes the volume.

The compilers, a team of editors, research assistants, and regional experts, have listed those studies which focus on "the internal structures and processes of family and kinship as well as their interaction within the larger society and with community, economic, legal, religious and educational institutions."-Pref. To limit this grand design, historical relevance is the chief criterion for selection. Items from disciplines other than history have been included only when their contribution to the history of the family experience has been significant. The bibliography is selective in other respects as well: the majority of references cite published monographs and journal articles, whereas doctoral dissertations, conference proceedings, and other "less accessible" literature are not as well represented. Items in nonWestern languages are included only if they have summaries in a Western European language. However, within its predetermined guidelines, the bibliography is a worthy effort that reflects in part the quantity, quality, and emphasis of research on family history in different areas of the world.-L.B.

Sakala, Carol. Women of South Asia: A Guide to Resources. Millwood, N.Y., Kraus International Publs., 1980. 517p. $\$ 18 ; \$ 9.95$ paper. LC $79-28191$. ISBN 0527-78574-1.

Although bibliographies on women in many regions of the world have proliferated since the International Women's Year in 1975 , a comprehensive bibliography on the 400 million women of South Asia has been lacking until the appearance of this impressive volume, which includes primary and secondary Western-language sources on historical and contemporary India, Pakistan, Bangladesh, Sri Lanka, and Nepal.

Part $I$ is a bibliography of more than 4,600 books, essays, articles, serial titles, films and recordings, and those doctoral dissertations published by University Microfilms International. The list is based on the holdings of the South Asian collection at the University of Chicago's Regenstein Library; most items were published between the late eighteenth century and 1979 . In the very detailed classification scheme general materials are listed first; then more specific titles are arranged in chronological time periods and in geographic contexts. Most entries include descriptive annotations. Part II consists of reports submitted by four scholars on research resources available in libraries, archives, and local collections in India, Pakistan, Bangladesh, and England. There is an author index to part I; the subject index covers both parts.

This work has a particularly individual stamp. The author notes, for example, that "the major divisions of the outline . . . do not correspond to western academic categories, but describe historical periods and cultural areas significant for South Asia and 
South Asians."-Introd. The subject index also employs a very hierarchical structure, evidently assuming that the user interested in Kali will go directly to "goddesses" without need of a see reference; similarly, there is no reference from "dowry" to "kinshipmarriage - economic transactions." The user will want to supplement this volume with other bibliographies on women in individual South Asian countries for more complete coverage of foreign academic theses and documents. Scholars in both South Asian and women's studies will welcome this volume for its scholarly quality, its utility, and, last but not least, its bargain price.D.G.

\section{Political SCIENCE}

Findling, John E. Dictionary of American Diplomatic History. Westport, Conn., Greenwood Pr:, [1980]. 622p. \$39.95 LC 79-7730. ISBN 0-313-22039-5.

Findling has selected 500 people and more than 500 events, conference names, catchwords, etc., for inclusion in this volume. For each he gives brief factual treatment, includes some critical statement as to the effect on American diplomatic history, and ends with a brief bibliography. The names of the U.S. chiefs of mission were "winnowed" to a manageable number and to these were added "a selection of non-diplomatic personnel, businessmen and missionaries, and publicists, including correspondents and broadcasters who had an impact on history."-Introd. Excluded are presidents who did not have a diplomatic career, and foreign diplomats and statesmen. Thus we have Washington Irving, John Quincy Adams, Charles A. Beard, and Eleanor Roosevelt, but neither Franklin nor Theodore Roosevelt, nor do we find many of the post-World War II chiefs of mission since very few of them had any substantial role in United States diplomatic policy. Nonbiographical entries range from the "SALT talks" to "Counselor" and "Council on Foreign Relations." The compiler omitted wars and the Department of Defense and its "military activities abroad," feeling that the "major portion of defense concerns is now with diplomacy."

There are five handy appendixes: "Chro- nology of American Diplomatic History" (which covers 1775-1978); "Key Diplomatic Personnel Listed by Presidential Administration"; "Initiation, Suspension, and Termination of Diplomatic Relations"; "Place of Birth"; and, most useful of all, "Location of Manuscript Collections and Oral Histories." A good index concludes the volume.

This dictionary and the Encyclopedia of American Foreign Policy (Suppl. DB27) complement each other nicely. There is very little duplication of persons chosen for inclusion and, of course, the Dictionary has no survey articles. The volume should be useful to all levels of readers not only for identification and quick definition, but also for the short bibliographies and the appendixes.-E.M.

\section{ARCHAEOLOGY}

The Cambridge Encyclopedia of Archaeology. Ed. by Andrew Sherratt. New York, Crown/Cambridge Univ. Pr., [1980]. 496p. il., maps. \$35. LC 78-16232. ISBN 0-517-53497-5.

In an "attempt to summarize the present state of knowledge over the whole field of archaeological inquiry" (Introd.), this compilation presents sixty-two short chapters by more than fifty scholars, which treat the origin and development of archaeology and describe the cultures and areas of its activity throughout the world. Part I is devoted to the origin and development of the discipline, its recent advances, and current trends. Part II, the major portion of the book, offers more than fifty short essays that delineate the history and archaeology of cultures throughout the world, from man the hunter to the early Middle Ages. The empires of the Old World, the East, the New World, and the Pacific are all included. Part III, "Frameworks: Dating and Distribution," includes three articles on methods of dating and on chronologies. Contributors are identified. Bibliographical notes for each chapter, a list of books for further reading, and an index conclude the work. Illustrations, many in color, and a double-column page of good design make for an attractive format. The volume is more likely to be used for browsing than for quick reference. $-R$.K. 


\section{Area Studies}

Nunn, Godfrey Raymond. Asia: Reference Works; a Select Annotated Guide. London, Mansell, 1980. 365p. \$55. ISBN 0-7201-0921-3.

Although based on Nunn's Asia, a Selected and Annotated Guide (1971; Guide DE1), this is virtually a new work, less than a third of the 1,567 titles in the present edition having been retained without change from the earlier publication. As before, a regional/country arrangement is used for the annotated listings of encyclopedias, handbooks, yearbooks, dictionaries, directories, atlases, gazetteers, chronologies, statistical sources, and bibliographies; various new subcategories were added in the bibliography sections. Oriental and Westernlanguage (mainly English) materials are cited. In addition to the author and title index, a table of "Chinese, Japanese and Korean Characters for Titles" is provided (transliteration being used in the text of the guide). The volume represents a thorough revision and updating of a very useful work.-E.S.

\section{NEW Editions, SuPPLEMENTS, ETC.}

With the completion (in 685 volumes) of the National Union Catalog-Pre-1956 Imprints (Guide AA96), the gap left for the $\mathrm{Bi}$ ble entries (volumes 53-56) has at last been filled. A special introduction, with notes on arrangement of the Bible cards, is provided in volume 53 . The four volumes encompass some 63,000 entries representing editions of the Bible in about 700 languages and dialects. The Bible segment is available separately as a five-volume set (London, Mansell, 1980. \$440) with an index of some 18,000 entries, but was not available for examination at this writing. The first installment of supplementary volumes for the "Pre-'56" set has also appeared; it continues the numbering of the basic series.

In the new subtitle "Répertoire Cumulatif des Livres de l'Année-Biblio," the recently published volumes of La Librairie Française, Tables Décennales 1966-1975 (Paris, Cercle de la Librairie, 1979. 6v. 289F.) acknowledge the source of the listings therein: Les Livres de l'Année-Biblio (Guide
AA617) and its predecessors. This cumulation continues the separate author and title listings as found in the earlier volumes of La Librairie Française (Guide AA615).

Compiled under the editorship of $\mathrm{L}$. Dawn Pohlman, the third edition of $A$ Union List of Selected Microforms in Libraries in the New York Metropolitan Area (New York, New York Metropolitan Reference and Research Library Agency, 1979. 181p. METRO Misc. Publ. no.22. $\$ 30$ prepaid) adds about 300 entries for major microform series and selected items of scholarly interest in microform. Observance of somewhat stricter guidelines led to the elimination of some 75 items from the previous edition (1975); 922 entries are now included. Indexes and finding aids for individual collections and series are again noted; some of the descriptive notes have been expanded.

The introduction to the ninth edition of Library of Congress Subject Headings (Washington, D.C., Library of Congress, 1980. $2 v$. \$75) notes two major changes made by the computer program for this list: "First, the previously announced adoption of indirect local subdivision has been implemented with the substitution of the instruction (Indirect) for (Direct) . . . Second, many free-floating form and topical subdivisions were removed from the list under specific subjects if no cross-references to the subdivisions were involved." Headings established and applied through December 1978 are included.

The fourth edition of Hans Wehr's Dictionary of Modern Written Arabic (ArabicEnglish), edited by J. Milton Cowan (Wiesbaden, Harrassowitz, 1979. 1,301p. DM198), incorporates some 13,000 new entries for new words and usages, idiomatic phrases, etc. Additions and deletions were accomplished by "cutting and pasting" rather than resetting, with some resulting inconsistencies in presentation and arrangement.

Some 600 titles are included in the second, revised edition of Black Periodicals and Newspapers (Madison, State Historical Society of Wisconsin, 1979. 83p. $\$ 3.50$ paper). Subtitled "A Union List of Holdings in Libraries of the University of Wisconsin and the Library of the State Historical Soci- 
ety of Wisconsin," the work gives holdings and locations of both current and defunct publications representing all phases of American black thought and action. Although limited to the libraries indicated, the combined holdings are believed to constitute one of the strongest collections in the field.

Covering the years 1956-60, "Supplement Six" (New York, Scribner, 1980. 769p. \$55) of the Dictionary of American Biography (Guide AJ41) offers biographical sketches of 524 persons by some 450 contributors. The $D A B$ and its supplements now include a total of 17,084 biographies.

C. Hugh Holman is again the editor of $A$ Handbook to Literature, now in its fourth edition (Indianapolis, Bobbs-Merrill, 1980. 537p. $\$ 7.50$ paper; 3d ed. 1972; Guide BD42). In addition to various revisions and corrections, there are some 200 new terms (including terms relating to film criticism) that "reflect the rapidity of critical change during the past seven years."-Pref.

Poetry Explication: A Checklist of Interpretation Since 1925 of British and American Poems, Past and Present is now available in a third edition (Boston, G. K. Hall, 1980. 570p. \$35). Prepared under the editorship of Joseph M. Kuntz and Nancy C. Martinez, this useful work "incorporates the checklists of 1950 and 1962 [Guide BD486] and, following the same aim, scope and limitations established for the first editions, lists explications printed through 1977, with an occasional excursion into 1978."-Introd.

Chapters on carols, ballads, and John Lydgate make up volume 6 of A Manual of the Writings in Middle English (New Haven, Conn., Academy of Arts \& Sciences, dist. by Shoe String, 1980. \$25). As in the earlier volumes (Guide BD389), there is an extensive bibliography for each chapter, with some citations from the late 1970s noted in this volume.

About 1,500 new entries appear in the second edition of Halliwell's Film Guide, edited by Leslie Halliwell (New York, Scribner, 1979. 1,018p. \$24.95); these include films released to autumn 1978, a selection of outstanding silent films, significant foreign-language films, and some English-language films omitted from the earlier edition (Suppl. BG44). Television movies have been dropped and now appear in a separate publication, Halliwell's Teleguide.

First of a proposed series of similar biographical dictionaries, Paul G. Partington's Who's Who on the Postage Stamps of Eastern Europe (Metuchen, N.J., Scarecrow, 1979. 506p. \$29.50) offers brief biographies of major and minor figures commemorated on postage stamps of Albania, Bulgaria, Czechoslovakia, East Germany, Hungary, Poland, Rumania, and Yugoslavia. Because it provides information on many persons not usually treated in English-language sources, the work has utility well beyond the field of philately.

Sponsored by the Federal Council on the Arts and the Humanities, Cultural Directory II (Washington, D.C., Smithsonian Institution Pr., 1980. unpaged. $\$ 7.75$ paper) is an updated edition of the guide published in 1975 (Suppl. CA25). The directory has been expanded to include descriptions of federal government support programs for the humanities as well as the arts, with some 300 programs and activities now listed.

New editions of two valuable bibliographies of geographical serials by Chauncy D. Harris have recently appeared. The fourth edition of his Annotated World List of Selected Current Geographical Serials (Chicago, Univ. of Chicago, Dept. of Geography, 1980. 165p. Research Paper 194. \$8 paper; 3d ed. 1971, Guide CL31) has been expanded to include 443 current serials (202 of them mainly in English) from 72 countries. The third edition of the International List of Geographical Serials (Chicago, Univ. of Chicago, Dept. of Geography, 1980. 457p. Research Paper 193. $\$ 8$ paper; 2d ed. 1971; Guide CL32), again coedited by Jerome D. Fellmann, is subtitled "A Comprehensive retrospective inventory of 3,445 geographical serials from 107 countries in 55 languages with locations in union lists."

A Guide to Historical Method, edited by Robert Jones Shafer, has appeared in a third edition (Homewood, Ill., Dorsey Pr., 1980. 272p. $\$ 9.50$ paper). Major changes from the 1974 edition (Guide DA7) include the addition of a section on quantitative method and expansion of the material on writing. 
Christine Steinberg and John Paxton have again brought up to date Sigfrid H. Steinberg's Historical Tables (Guide DA47). The tenth edition (New York, St. Martin's, 1979. 269 p. \$22.50) covers through 1978, and the tables from 1945 have been rearranged.

Like the volumes covering 1913-65 (Guide EA214), the Isis Cumulative Bibliography 1966-1975 (London, Mansell,
1980. v.l: 483p., $\$ 92.50$ ), edited by John $\mathrm{Neu}$, cumulates the references from the "Critical Bibliography of the History of Science" appearing annually in Isis. Volume 1 lists, in separate sections, all items referring to individuals and to institutions; a second volume of this supplement will list references to topical subjects.-E.S.

College 6 Research Libraries is published six times a year by the American Library Association, $50 \mathrm{E}$. Huron St., Chicago, IL 60611. American Library Association, owner; C. James Schmidt, editor. Second-class postage paid at Chicago, Illinois. Printed in U.S.A. As a nonprofit organization authorized to mail at special rates (Section 132.122, Postal Service Manual), the purposes, function, and nonprofit status of this organization, and the exempt status for federal income tax purposes, have not changed during the preceding twelve months.

\section{Extent and Nature of Circulation}

("Average" figures denote the number of copies printed each issue during the preceding twelve months: "Actual" figures denote number of copies of single issue published nearest to filing date- the July 1980 issue.) Total number of copies printed: Average, 13,050; Actual, 13,050; Paid circulation: not applicable (i.e., no sales through dealers and carriers, street vendors and counter sales). Mail subscriptions: Average, 11,260; Actual, 11,133. Total paid circulation: Average, 11,260; Actual, 11, 133. Free distribution by mail, carrier, or other means, samples, complimentary and other free copies: Average, 1,417; Actual, 1,465. Total distribution: Average, 12,677; Actual, 12,598. Copies not distributed: office use, left-ocer, unaccounted, spoiled after printing: Average, 373; Actual, 452. Returns from neus agents: not applicable. Total (sum precious three entries): Average, 13,050, Actual, 13,050.

Statement of Ownership. Management, and Circulation (PS form 3526, Aug. 1978) for 1980 filed with the United States Post Office. Postmaster in Chicago, Illinois, October 2, 1980. 